\title{
Numerical Analysis of Wagon Leaf Spring Using Ansys 14.5
}

\author{
Mladen Krstić ${ }^{*}$, Branislav Milenković ${ }^{2}$, Đorđe Jovanović ${ }^{2}$
}

${ }^{1}$ Faculty of Mechanical and Civil Engineering Kraljevo, University of Kragujevac, Kraljevo (Serbia)

${ }^{2}$ Mathematical Institute of Serbian Academy of Sciences and Arts, Belgrade (Serbia)

Leaf spring are widely used for the suspension system in trains and commercial vehicles to absorb vibrations and shocks. This paper deals with the methodology of analysis of the leaf springs of the freight railway wagons by using software package Ansys 14.5. The methodology is applied in a concrete example of leaf spring for axle load of $225 \mathrm{kN}$. The procedure of forming the CAD model of the leaf spring using AutoCad and Autodesk Inventor is exposed, as well as the development of numerical model in Ansys software package. The results of the static analysis of given leaf spring are presented and commented.

Keywords: Leaf spring, FEM analysis, Wagon, Ansys

\section{INTRODUCTION}

A leaf spring is a type of spring made by a number of plates (leaves) stacked upon each other in descending order of size. It is used to absorb shocks and vibrations in heavy commercial vehicles like trucks, trains, buses, etc.

The leaf spring provides quite a few major advantages. Below, we have mentioned a few of the main benefits:

- Leaf springs are simple in design

- Leaf springs are light in weight and strong

- Leaf springs provides good damping action

- Leaf springs provides good support to the axle and the chassis

- Leaf springs can withstand a large amount of load when compared to helical springs

However, leaf springs have a series of shortcomings: manufacturing process and their maintenance is more expensive than other types of springs, their mass is larger, leaves are exposed to damage, friction force between the leaves depends upon the state of contact surfaces, and they are not convenient for horizontal impact amortization. Besides, they are not resistant to small forces, transmitting them to the solid body, thus leading to vibration and noise. It is for this reason that the contemporary passenger cars do not possess leaf springs. They can however be found only in older models of passenger cars.

There are five different types of leaf springs:

- Transverse

- Elliptic

- Semi-elliptic

- Quarter-elliptic

- Three quarter elliptic

Different types of leaf springs are shown in Figure 1.

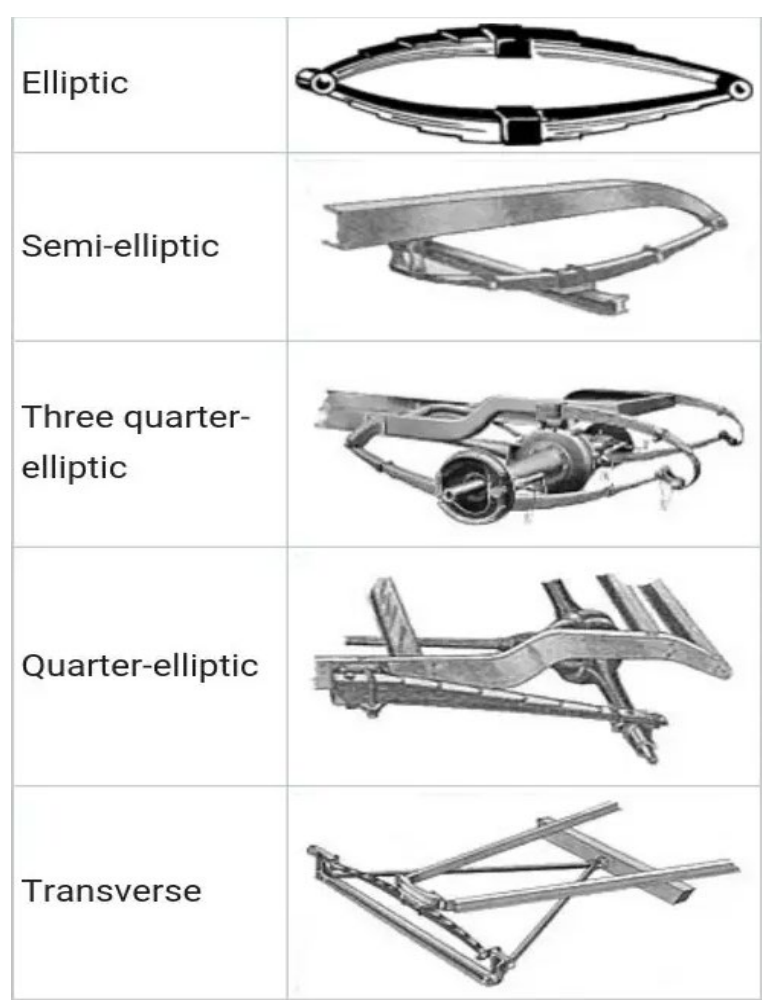

Figure 1:Types of leaf spring

The material used for leaf springs is usually a plain carbon steel having 0.90 to $1.0 \%$ carbon. The leaves are heat treated after the forming process. The heat treatment of spring steel produces greater strenght and therefore greater load capacity, greater range of deflection and better fatique propeties.

The complete of leaf spring is composed of the main leaf (with eyes), other leafs, spring buckle and wedge. Leafs are made of steel tapes which are bend in certain radius and subjected to the thermal treatment. Every leaf has on its upper side the longitudinal groove and on bottom side the appropriate longitudinal rib, which prevents mutual lateral movement of the leafs. The main 
leaf has on its ends the eyes for connection with the wagon underframe or bogie frame.

The characteristic construction and dimensions of the leaf spring are shown in Figure 2.

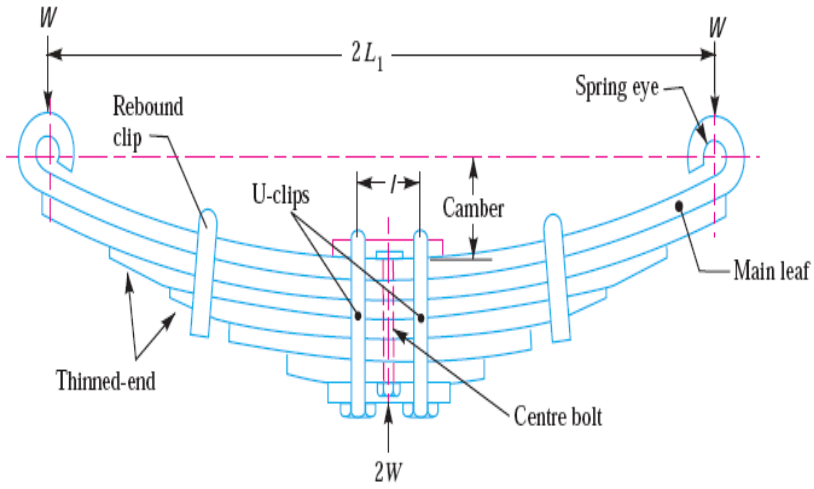

Figure 2: The characteristic construction of the leaf spring

In this paper we use FME analysis to solve static analysis of the leaf spring using modern software packages Ansys $14.5[1,3]$.

\section{LOAD CASES FOR LEAF SPRING CALCULATION}

In this Section, a leaf spring on a 4-axle tank wagon with the following parameters was analyzed:

$G_{k}=210 \mathrm{kN}$-mass of the empty wagon

$G_{o s}=14,5 \mathrm{kN}-$ mass of the wheelset

$G_{g}=1,2 \mathrm{kN}-$ mass of the leaf spring

$n_{o s}=4$ - number of axles

$n_{g}=8$ - number of leaf spring

$P_{o s}=225 \mathrm{kN}$ - maximum axle load

For leaf spring for axle load of $225 \mathrm{kN}$ considered in this paper, the specific load cases are calculated in [2], and those are:

Load case 1: The load of the leaf spring under empty wagon

$$
F_{k}=\frac{G_{k}-n_{o s} \cdot G_{o s}-n_{g} \cdot G_{g}}{n_{g}}=\frac{210-4 \cdot 14,5-8 \cdot 1,2}{8}=17,8 \mathrm{kN}
$$

Load case 2: The load of the leaf spring under fully loaded wagon

$$
F_{t}=F_{k}+\frac{G_{t}}{n_{g}}=17,8+\frac{690}{8}=104,05 \mathrm{kN}
$$

Load case 3: The load of the leaf spring under fully loaded wagon in the dynamic regime

$$
F_{\text {max }}=k_{d} \cdot F_{t}=1,3 \cdot 104,05=135,265 \mathrm{kN}
$$

The required stiffness, dimensions, number of leafs, stresses and safety factor, are determined. The defined geometry and the previous load cases are used for demonstration of procedure of analytical calculation of the leaf spring, as shown in the next chapters.

\section{FORMING CAD AND FEM MODEL}

The first step is modelling the main leaf in 2D surrounding, for which AutoCAD is the most favourable, and it is used in this case.
In next phase, formed dwg or dxf file with sketch is imported in software for 3D modelling - in this case Autodesk Inventor is used. After this, it is very simple to obtain 3D geometry of main leaf, as shown in Figure 3.

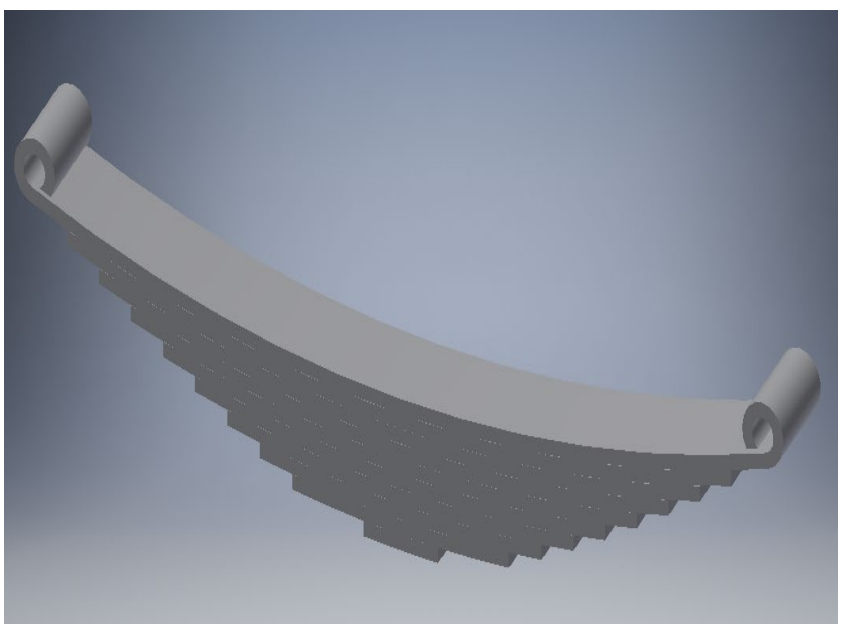

Figure 3: The 3D geometry of leaf spring formed in Autodesk Inventor

The basis for forming the FEM model is previously formed CAD geometry which is imported in Ansys in form of IGES or STEP file.

\begin{tabular}{|c|c|c|c|c|c|}
\hline Chart & Alternating Stress Outhe Row 3: Stuctura Itteel & & & & 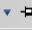 \\
\hline & A & B & & & E \\
\hline 1 & Property & Value & & & 6 \\
\hline 2 & Density & 7850 & $\mathrm{kgm}^{\wedge}-3$ & \pm[ & 可 \\
\hline 3 & 曰 Th Isotopic Secant Coefficient of Thermal Expansion & & & 鸟 & \\
\hline 4 & 7 Coefficent of Thermal Expansion & 1.2E-05 & $c^{\wedge}-1$ & 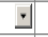 & 罒 \\
\hline 5 & Z Reference Temperature & 22 & c & $\doteq$ & 鴫 \\
\hline 6 & 日 Z Isotopic Elastiaty & & & 近 & 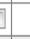 \\
\hline 7 & Derive from & Young's Modulus an... $\doteq$ & & & 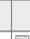 \\
\hline 8 & Young's Modulus & $2 \mathbb{E}+11$ & $\mathrm{~Pa}$ & \pm & 回 \\
\hline 9 & Poisson's Ratio & 0.3 & & & 回 \\
\hline 10 & Bulk Modulus & $1.666 \pi+11$ & $\mathrm{~Pa}$ & & 回 \\
\hline 11 & Shear Modulus & $7.6923 E+10$ & $\mathrm{~Pa}$ & & 四 \\
\hline 12 & $\exists$ Alternating Stress Mean Stress & Tabular & & 匠 & 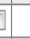 \\
\hline 13 & Interpolation & $\log \operatorname{tog}$ & & & 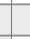 \\
\hline 14 & Scale & 1 & & & 四 \\
\hline 15 & Offset & 0 & $\mathrm{MPa}$ & & 目 \\
\hline 16 & \& $Q 7$ Stain-ife Parameters & & & 㢳 & 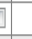 \\
\hline 17 & Display Curve Type & Strain-Life & & & \\
\hline 18 & Strength Coefficient & 2063 & $\mathrm{MPa}$ & \pm & 四 \\
\hline 19 & Strength Exponent & -0.08 & & & 罒 \\
\hline 20 & Ductility Coefficient & 9.56 & & & 圆 \\
\hline 21 & Ducdility Exponent & -1.05 & & & 回 \\
\hline 22 & Cydic Strength Coefficient & 2432 & $\mathrm{~Pa}$ & $\dot{\nu}$ & 圆 \\
\hline 23 & Cydic Strain Hardening Exponent & 0.13 & & & 司 \\
\hline 24 & Tensile Yield Strength & 1100 & $\mathrm{MPa}$ & \pm[ & 回 \\
\hline 25 & 7 Compressive Yield Strength & 1100 & $\mathrm{MPa}$ & \pm[ & 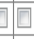 \\
\hline 26 & Z7t Tensile Ultimate Strength & 1300 & $\mathrm{MPa}$ & $\dot{I}[$ & 回 \\
\hline
\end{tabular}

The values of parameters of the leaf spring material (spring steel 51Si7) are put in Ansys 14.5. (Figure 4).

Figure 4: Values of parameters of the leaf spring material

In the next phase, supports are adjusted, as shown in Figures 5-7. 


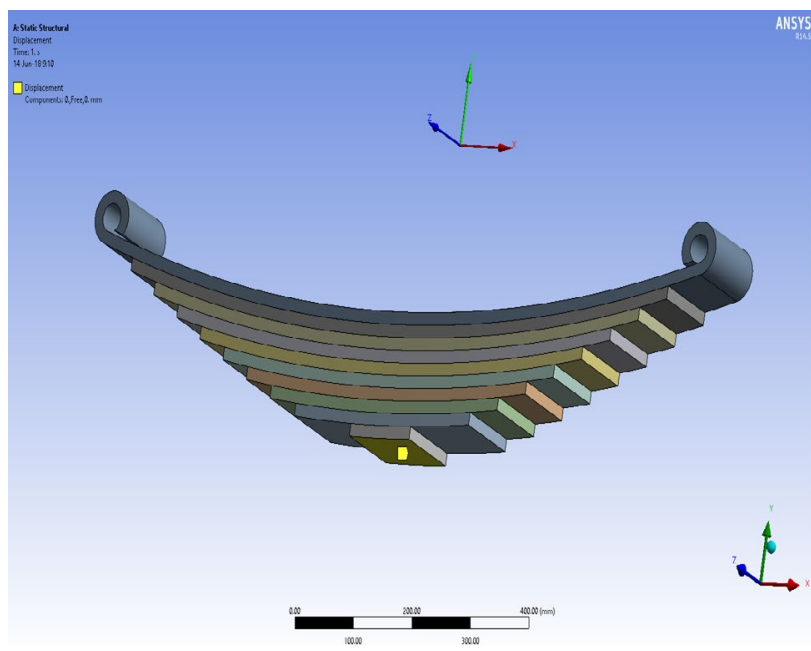

Figure 5: Support 1. - only vertical translation allowed

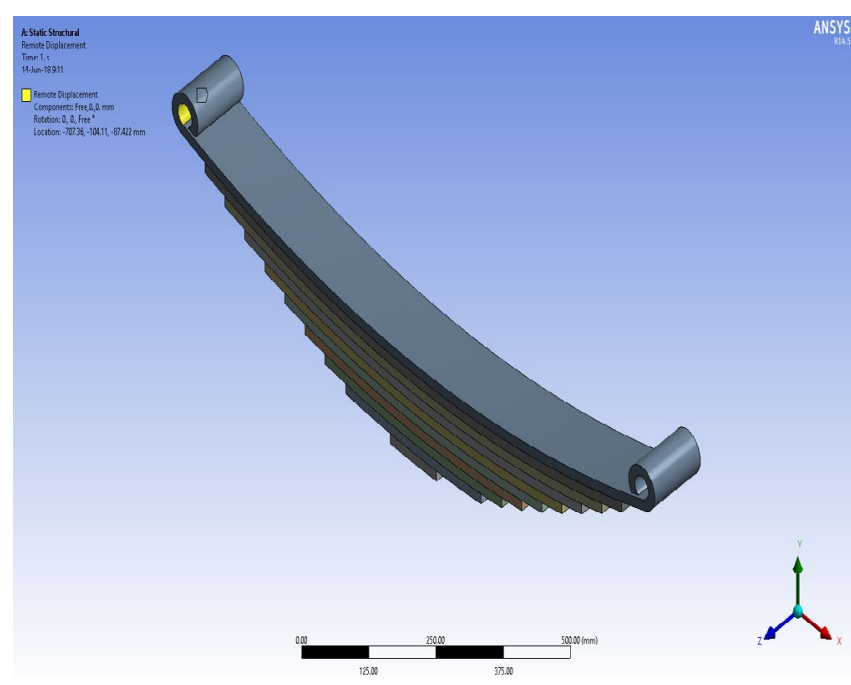

Figure 6: Support 2. - rotation and horizontal translation allowed

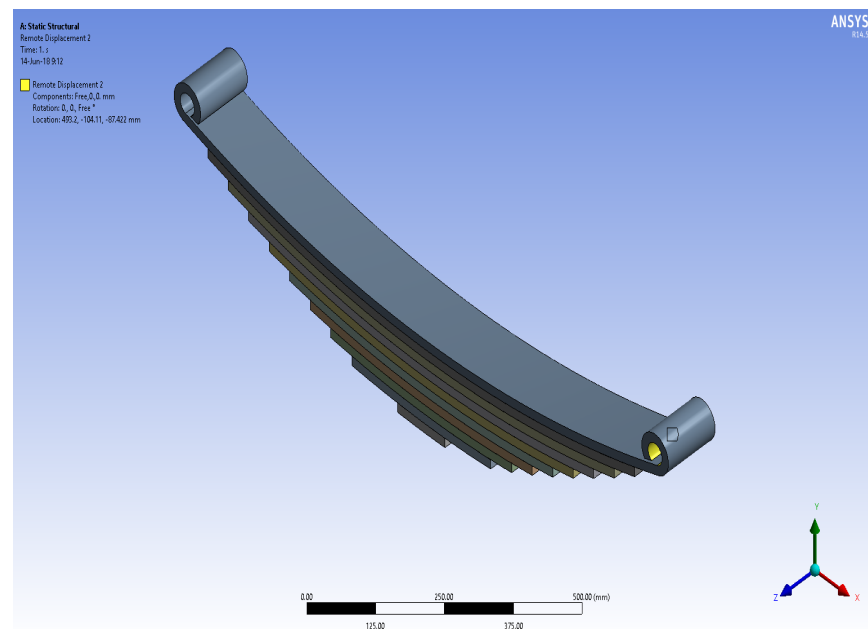

Figure 7: Support 3. - rotation and horizontal translation allowed

The finally generated FEM model is composed of 28158 finite elements and 109598 joints (Figure 8).

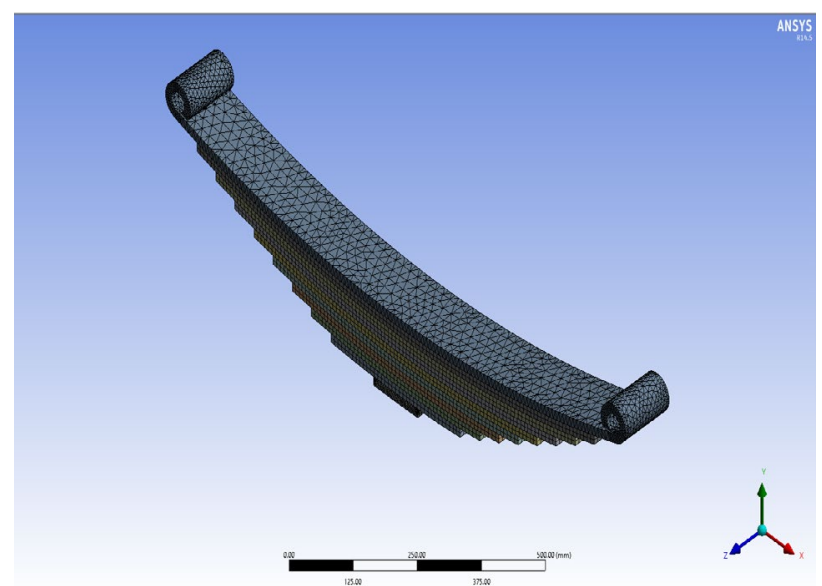

Figure 8: The finally formed FEM model of the leaf spring in Ansys 14.5

The applied force for third load case is shown in Figure 9.

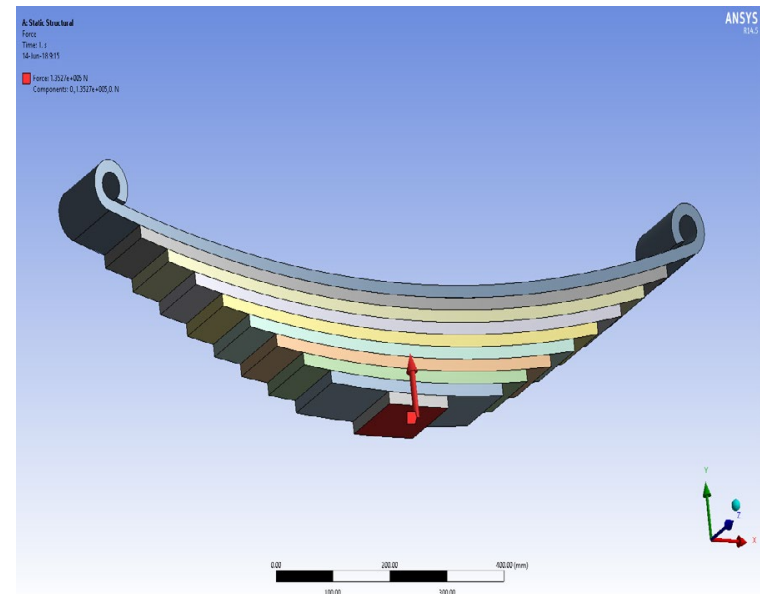

Figure 9:The applied force for third load case

\section{NUMERICAL RESULTS}

The obtained results for given load cases are shown in Figures 10-15.

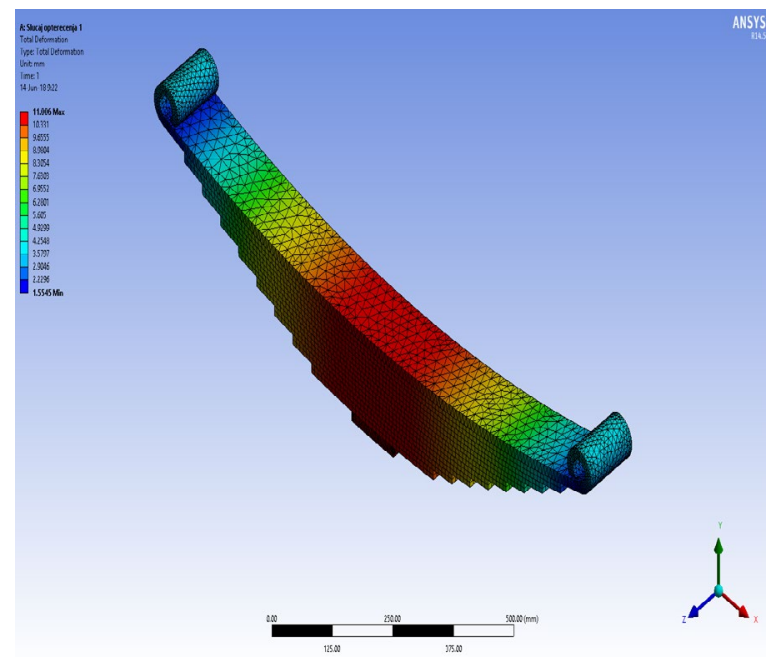

Figure 10: The deflection for load case 1 


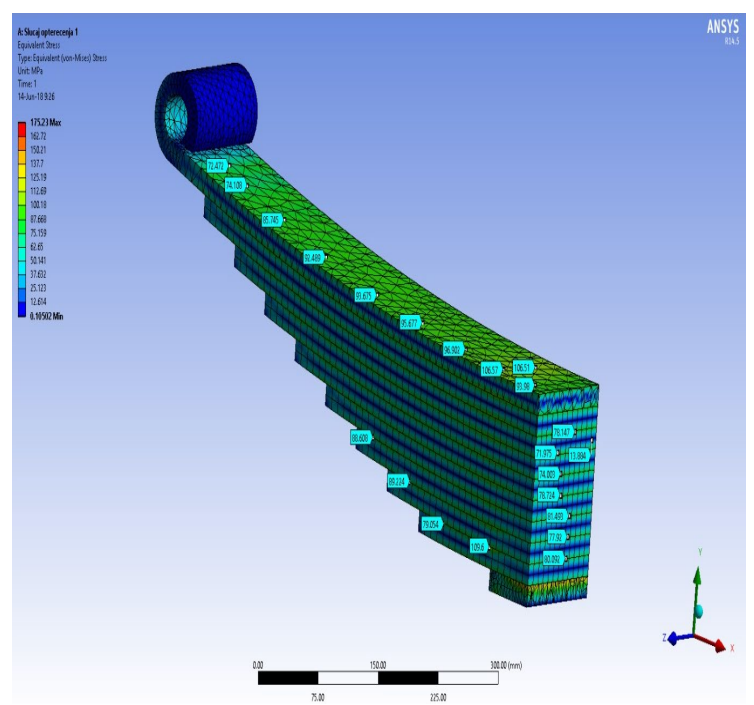

Figure 11: The equivalent stress for load case 1

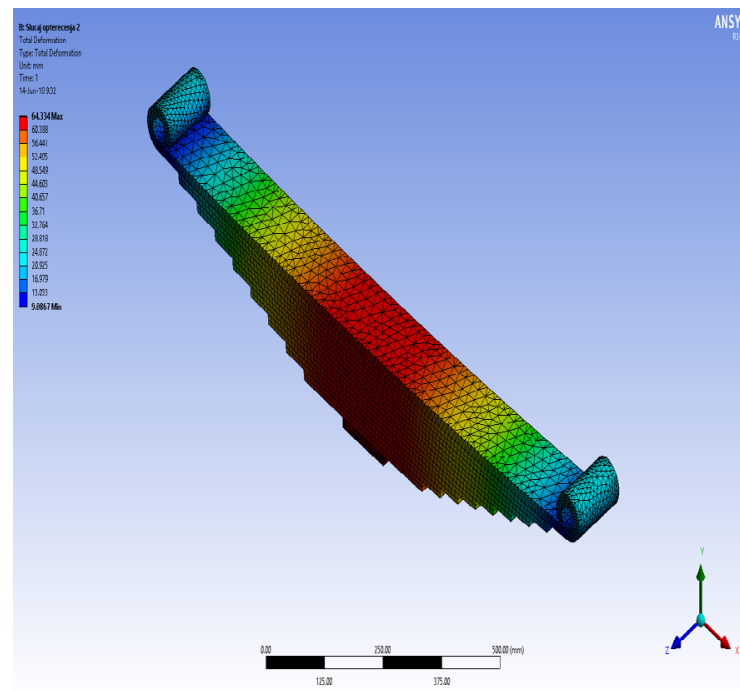

Figure 12: The deflection for load case 2

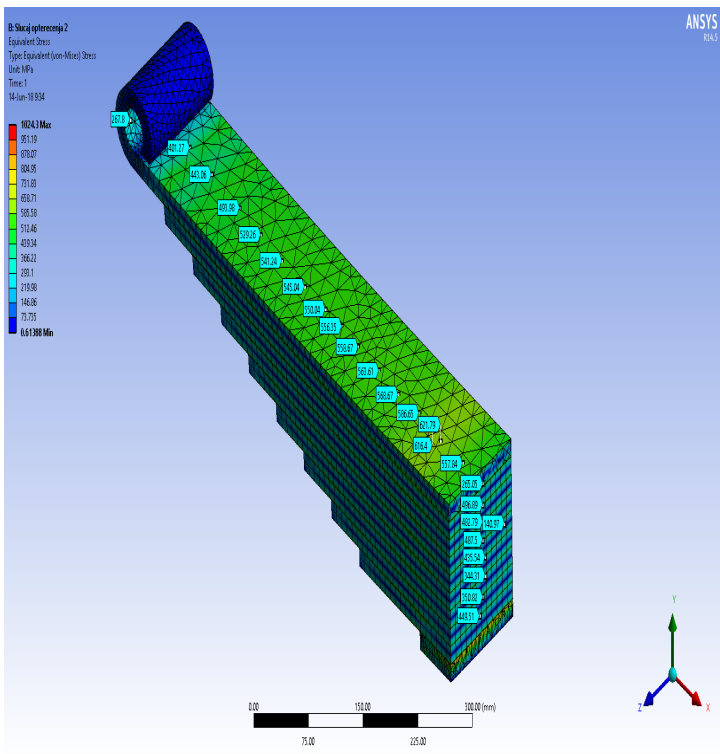

Figure 13: The equivalent stress for load case 2

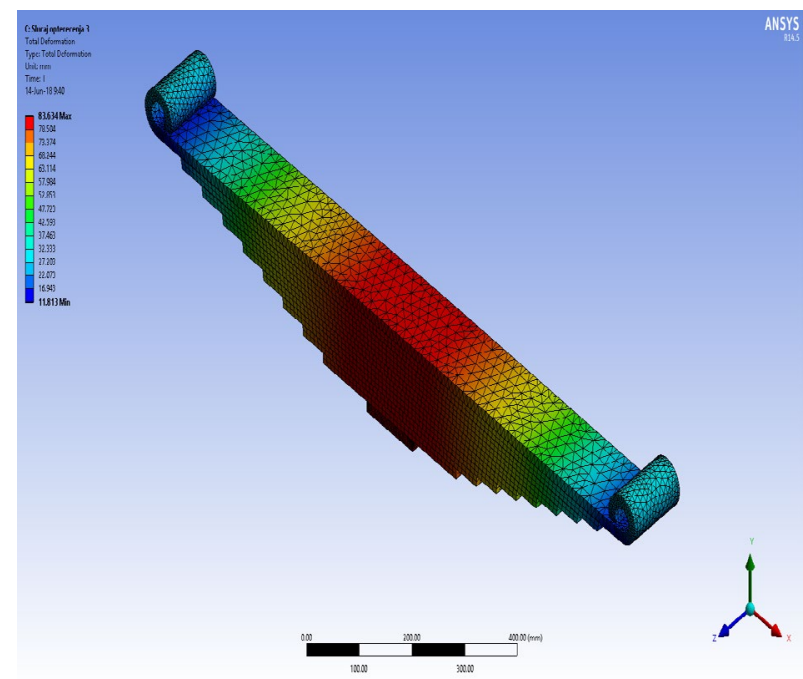

Figure 14: The deflection for load case 3

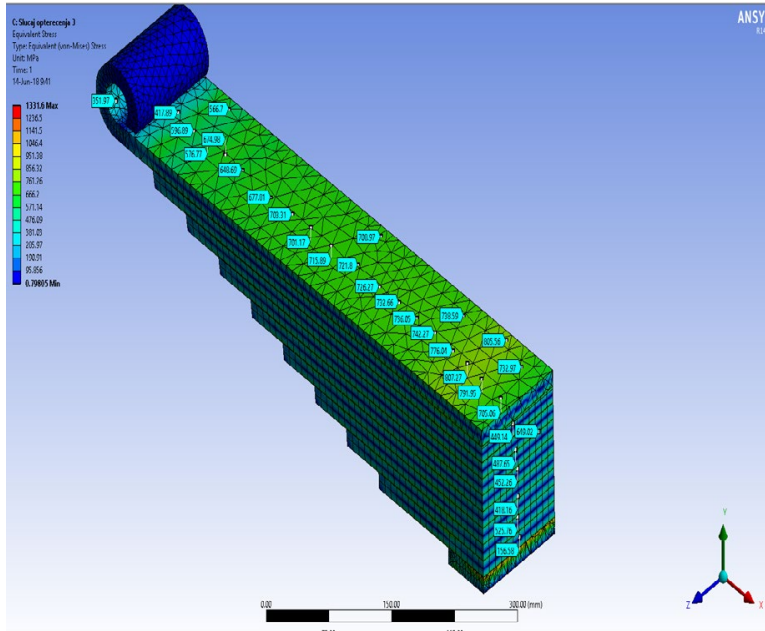

Figure 15: The equivalent stress for load case 3

In the final stage, the results obtained by the numerical calculation are compared with the results of analytical calculation (exposed in literature [2]).

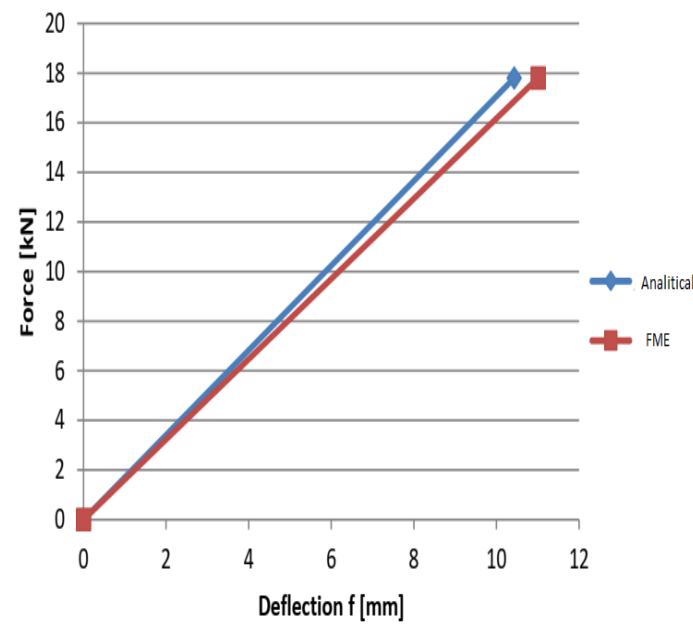

Figure 16: The comparative diagram of leaf spring deflection obtained by the FEM and analytical way for load case 1 


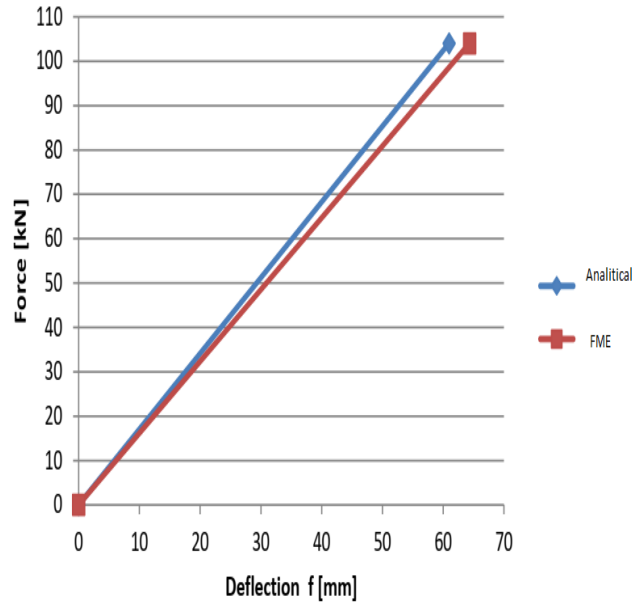

Figure 17: The comparative diagram of leaf spring deflection obtained by the FEM and analytical way for load case 2

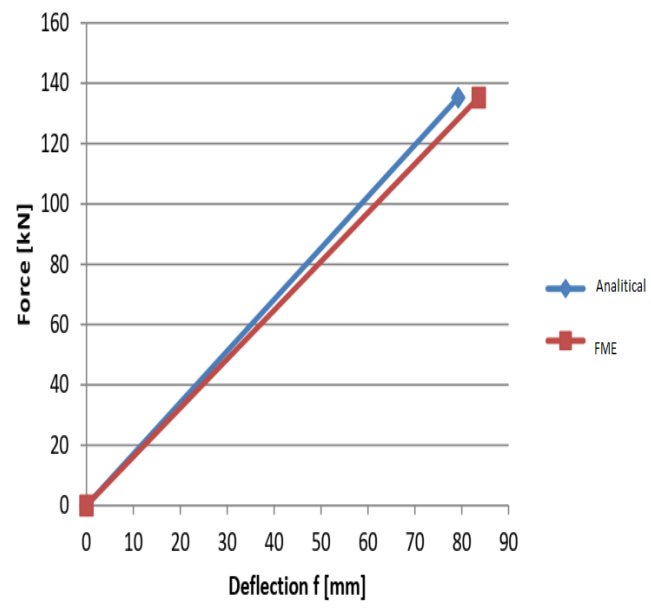

Figure 18: The comparative diagram of leaf spring deflection obtained by the FEM and analytical way for load case 3

\section{CONCLUSION}

This paper uses analytic and numeric (FME) methods for constructing a leaf spring of a passenger car (rail). Save for the analytic method, the finite element method - FME was used. The 3D model of the leaf spring was developed in Autodesk Inventor Professional software suite, while the FME analysis was performed using Ansys 14.5 software suite. Based on calculation results given by FME, a significant conclusion about the state of analyzed leaf spring construction can be drawn. In the first case, considering an empty wagon under the influence of a force of $17,8 \mathrm{kN}$, the deflection of the spring is $1,04 \mathrm{~cm}$, a characteristic result for such a force. In the second case, considering the full wagon under the influence of a force of $104,05 \mathrm{kN}$, the deflection of the spring is $6,09 \mathrm{~cm}$. This result was expected, and the value represents a difference of the arrow length between the empty and full wagon. In the third case, considering spring behavior under the influence of the maximum force of $135,26 \mathrm{kN}$, the deflection is $7,92 \mathrm{~cm}$, which is an expected result.

Based on obtained results, the following conclusion can be drawn: the analyzed construction of the leaf spring does satisfy all of the criteria, and it can be installed on the passenger car (rail).

\section{ACKNOWLEDGEMENTS}

This work was supported by the Serbian Ministry of Education, Science and Technological Development through Mathematical Institute of the Serbian Academy of Sciences and Arts.

\section{REFERENCES}

[1] Bižić. M, Petrović. D "Numerical analysis of wagon leaf spring", XIX Scientific-Expert Conference on Railways RAILCON 2020, 15-16 October, Serbia, Niš, pp.21-24.

[2] Petrović, D., Železnička vozila - Praktikum, Mašinski fakultet Kraljevo, Kraljevo, 2006.

[3] Gowd, H., Static Analysis of Leaf Spring, International Journal of Engineering Science and Technology, Vol. 4 , No. 08, pp. 3794-3803, 2012.

[4] Милосав Огњановић, Машински елементи, Машински факултет Београд, Београд,2013.

[5] http://www.tatravagonkabratstvo.rs/

\section{Numerička analiza lisnate opruge vagona korišćenjem Ansys 14.5}

Mladen Krstić ${ }^{*}$, Branislav Milenković², Đorđe Jovanović

${ }^{1}$ Fakultet za mašinstvo i građevinarstvo u Kraljevu, Univerzitet u Kragujevcu, Kraljevo (Srbija)

${ }^{2}$ Matematički institut Srpske akademije nauka i umetnosti, Beograd (Srbija)

Lisnate opruge se široko koriste za sistem vešanja u automobilima i komercijalna vozila da apsorbuju vibracije $i$ udare. Ovaj rad se bavi metodologijom analize lisnatih opruga terete železničkih vagona korišćenjem softverskog paketa Ansis 14.5. Metodologija je primenjena na primeru lisnate opruge za osovinsko opterećenje od $225 \mathrm{kN}$. Izložen je postupak formiranja CAD modela lista korišćenjem AutoCad-a i Autodesk Inventor-a, kao i razvoj numeričkog modela u softverskom paketu Ansys. Prikayani su $i$ analizirani Rezultati statičke analize date lisnate opruge.

Ključne reči: Lisnate opruge, FEM analiza, Vagon, Ansys 